\title{
Topotecan Every 28 Days Regimen
}

National Cancer Institute

\section{Source}

National Cancer Institute. Topotecan Every 28 Days Regimen. NCI Thesaurus. Code C160130.

A chemotherapy regimen consisting of topotecan every 28 days that may be used in the treatment of cervical cancer. 